\title{
Endüstriyel Tesisler için Güneş Duvarı Performansının İncelenmesi
}

\author{
Hacer AKHAN ${ }^{* 1}$, Doğan ERYENER ${ }^{1}$ \\ ${ }^{1}$ Trakya Üniversitesi, Mühendislik Fakültesi, Makine Mühendisliği Bölümü, Edirne
}

Geliş tarihi: 03.05.2017

Kabul tarihi: 31.05 .2017

$\ddot{O} \mathbf{z}$

Bu çalışmada, Türkiye'de uygulaması yapılan ilk hava sızdırmalı güneş duvarın saha performansının analizi yapılmıştır. 2012 yılında Çayırova-Kocaeli'nde bir otomotiv tesisinde ısıtma ve havalandırma amaçlı olarak uygulaması yapılan $770 \mathrm{~m}^{2}$ 'lik güneş duvarının performansı, iki yıllık bir süre zarfında kış dönemlerde üçer aylık periyodlar halinde bina yönetim sistemi vasıtasıyla incelenmiştir. Ayrıca, sistemin teorik analizi, bir güneş duvarı simülasyon yazılımı kullanılarak yapılmış ve elde edilen sonuçlar saha verileri ile karşılaştırılmıştır. Simülasyon sonuçlarına benzer olarak, 2013 yılında 113,037 kWh enerji, 2014 yılındaki 246,924 kWh 1s1 enerjisi üretmiş ve dönemsel olarak \%62 varan bir enerji tasarruf elde edilmiştir.

Anahtar Kelimeler: Güneş duvarı, Güneş enerjisi ile hava 1sıtma

\section{Investigation of Solar Wall Performance for Industrial Facilities}

\begin{abstract}
In this study, the performance of field tests of first unglazed transpired solar wall installation in Turkey is analyzed. The performance of the $770 \mathrm{~m}^{2}$ solar wall in an automotive plant in Çayrrova - Kocaeli in 2012, has been monitored for winter periods of two years via a building management system. In addition, the theoretical analysis of the system was made by a simulation software for solar wall and the results obtained were compared with the field data. Solar wall delivered $113.037 \mathrm{kWh}$ thermal energy in 2013, $246.924 \mathrm{kWh}$ thermal energy in 2014 and energy savings of up to $62 \%$ have been achieved, which are similar to simulated results.
\end{abstract}

Keywords: Transpired solar collector, Solar air heating

"Sorumlu yazar (Corresponding author): Hacer AKHAN, hacera@trakya.edu.tr 


\section{GíRiş}

Teknolojinin gelişmesi ve insan nüfusundaki artışla beraber enerji tüketimi artmaktadır. Mevcut enerji kaynaklarının tükeneceği düşüncesi, dönemsel olarak ortaya çıkan enerji krizleri, gün geçtikçe artan sera gazı emisyonları, çevre kirliliği ve iklim değişiklikleri, dünyanın her yerinde kaygı oluşturmaktadır. Küresel enerji talebi, iklim değişikliği ve çevre kirliliği, enerji verimli ve çevre dostu binaların inşasını son yıllarda gündeme getirmiştir. Genel olarak, binaların enerji ihtiyaçlarının tespit edilmesi, enerji türleri ve sera gazı emisyonları bakımından değerlendirilmesi, yeni veya mevcut binalar için bir minimum enerji performans düzeyinin belirlenmesi gerek ülkemizde gerekse dünyada çeşitli mevzuat, yasa ve yönetmeliklerle belirlenmiş ve bu konu geliştirilmeye devam etmektedir. Özellikle yenilenebilir enerji kaynaklarının bina kullanımında mümkün olan en yüksek seviyede kullanımı, tüm bu yönetmeliklerde tavsiye edilmektedir.

Genel olarak, binalardaki enerji tüketiminin ülke enerjisinde önemli bir paya sahip olduğu uzun yıllardır bilinen bir gerçektir. Dolayısıyla binaların enerji tüketimini azaltmak için konvansiyonel bazı önlemlerin yanı sıra yüksek verimli yenilenebilir enerji teknolojilerinin kullanımı önemlidir. Binalar için önerilen enerji kaynakları arasında en yaygın ve potansiyeli en yüksek olanlarından birisi güneş enerjisidir. Türkiye Yenilenebilir Enerji Genel Müdürlüğü Raporuna göre Türkiye'deki güneş enerjisi potansiyeli yaklaşı olarak yılda 380 milyar kWh/yıl'dır. Öte yandan, Uluslararası Enerji Ajansının raporuna göre [1], Türkiye, toplam 18.185.901 $\mathrm{m}^{2}$ 'lik güneş toplayıcısı ve yıllık 16.316 GWh güneşten enerji üretimi rakamları ile dünya genelinde özellikle güneşle su 1sıtma alanında lider ülkelerden biridir. Türkiye'deki güneş enerjisi potansiyeli diğer enerji türlerine kıyasla çok daha yüksek olmasına rağmen, uluslararası enerji ajansının raporunda da belirtildiği üzere, ülkemizdeki güneş toplayıcıları ağırlıklı olarak müstakil evlerde kullanma suyu 1sıtması amaciyla limitli olarak kullanılmaktadır. Oysa, ülkemizde 1sitma amaçlı olarak binalarda tüketilen ithal doğal gazın yüksek miktarları dikkate alındığında, Türkiye'nin güneş enerji potansiyelinin daha etkin bir şekilde kullanılması gerekliliği ortaya çıkmaktadır. Bununla birlikte, bu amaca hizmet eden binaya uygun yenilenebilir enerji teknolojilerinin pazara arzı da önemli bir başka parametredir. Günümüzde özellikle kuzey Amerika ve Avrupa'daki binalarda uzun yillardır kullanılan farklı yenilenebilir enerji teknolojilerinin Türkiye'de son zamanlarda

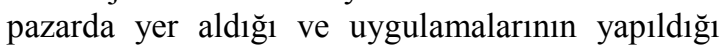
görülmektedir. $\mathrm{Bu}$ ürünler arasında, en önemlilerinden birisi, güneş enerjisi ile mahal 1sıtmasında uzun yıllardır kullanılan güneş duvarı sistemleridir. İlk olarak on dokuzuncu yüzyılda uygulanmaya başlanan güneş duvarları, binalardaki 1sıtma ve havalandirma yükünü azaltmak için kullanılan, düşük maliyetli ve yüksek verimli genel yapısı itibariyle basit enerji sistemleridir [2]. 20. yüzyıl ile birlikte gelişen güneş duvarı sistemleri arasında, özellikle geliştiricisinin adıyla anılan Trombe duvarı literatürdeki yerini almış, uzun yıllar güneş duvarı dendiğinde ilk akla gelen sistem olmuştur [3]. Doğal havalandırma tekniğini kullanarak pasif 1sitma yapan Trombe duvarları, uzun yillar müstakil evlerde uygulanmış buna karşın modern binaların yeni cephe sistemlerinde uygulama zorluğu nedeniyle istenen ve beklenen ölçüde yaygınlaşamamıştır.

Teknolojinin gelişimiyle birlikte, Trombe duvarı evrimleşmiş ve yerini zorlanmış havalandırma ile aktif 1sıtma yapan yeni güneş duvarı sistemlerine bırakmıştır. Yeni güneş duvar sistemleri arasında, özellikle hava sızdırma tekniği sahip olanlar oldukça ön plana çıkmış ve güneş duvarı uygulamalarını domine etmiştir. Bunun temel nedenlerinden birisi, sistemin ucuz ve basit yapısının yanı sıra hava sızdırma tekniği sayesinde çok noktadan emiş ile çok yüksek enerji dönüşüm verimliliğine ulaşıyor olmasıdır. Hava sızdırmalı güneş duvarlarının en önemli özelliği, güneşle 1sıtma işlemini taze hava kullanılarak gerçekleştiriyor olması ve böylece ısıtma ve havalandırma işlemlerinin bir arada yapılmasıdır. İlk olarak John Hollick [4] tarafindan seksenli yıllarda geliştirilmiş olan hava sızdırmalı güneş duvarları, basit yapısına rağmen son derece karmaşık bir 1sı transferi mekanizmasına sahiptir. 
Konuya ilişkin ilk teorik ve deneysel 1sı transferi incelemeleri, Kutscher ve Christensen tarafindan yapılmıştır [5]. Kutscher, güneş duvarı için 1s1 transferi denklemleri geliştirmiştir [6]. Cao ve arkadaşları, deneysel sonuçlara dayanarak, rüzgarlı koşul için oluklu geometriye sahip delikli paneldeki 1sı değiştirme etkinliği bağıntısı ifade edilmiştir [7]. Pesaran, hava sızdırmalı güneş toplayıcılarını kurutmalı soğutmada kullanmıştır [8]. Kutscher, emme debisi yandan esen rüzgar etkisi, delik mesafesi ve delik çapı parametreleri için toplayıcı 1sı değiştirici verimini hesaplamak amacıyla laboratuvar çalışması gerçekleştirmiştir [9]. Basınç kayıplarını ifade eden bir denklem bulmuştur. Van Decker, üç boyutlu akış için toplayıc1 1sı değiştiricisi verimini incelemiştir [10]. Model, üç 1sı transferi mekanizmasına sahiptir: Panelin ön yüzeyi, delik içi, panelin arka tarafi. Hava özellikleri, rüzgar hızı, 1sıl iletkenlik, delik çap1, gözeneklilik ve emme hızının fonksiyonu olarak 1sı değiştiricisi verimi modellenmiştir. Van Decker ve arkadaşları, rüzgarsız koşul için kare veya üçgen mesafeli dairesel delikli toplayıcının verim denklemini geliştirmiştir $[11,12]$. Toplayııı içindeki akış dağılımını anlayabilmek için emme, hız profili, farklı kolektör yüksekliği, yükseklikderinlik oranı, güneş 1şınımı, kolektör alanı için debi değeri verim gibi önemli parametreleri etkisini incelemiştir. Campbell-Howe, hava sızdırmalı güneş toplayıcılarının ekonomik analizini ve 1sıl simülasyonunu yapmıştır [13]. Dymond ve Kutscher, toplayicı tasarımında kullanılan farklı geometrik konfigürasyonları içeren bilgisayar modeli geliştirilmiştir [14, 15]. Model, tüm 1sı transferi mekanizmalarını ve basınç kayıplarını içermekteydi. Christensen, 1sıl iletkenliği düşük olan absorber panele sahip hava sızdırmalı güneş toplayıcısı üzerine çalışma yapmıştır [16]. Arulandanam, dairesel delikli kare mesafeli toplayıcının verimini hesaplayan CFD kodu kullanmıştır [17]. Model, rüzgarsız koşul için geliştirildi ve panelin arka tarafındaki ısı transfer hesaplamalarını da içermektedir. Gunnewiek ve arkadaşları, rüzgarın hava sızdırmalı güneş toplayıcısındaki akış dağılımına etkisini incelemiştir [18]. Gunnewiek, rüzgar etkisinin toplayıcı iç hacmindeki akışa etkisini incelemiştir [19]. Maurer, hava sızdırmalı güneş toplayıcılarının sıcak iklim koşullarındaki performansını incelemiştir [20]. Augustus ve Kumar, hava sızdırmalı güneş toplayıcılarının ısıl performans analizini ve matematiksel modellemesini geliştirmişlerdir [21]. Naveed ve arkadaşları, fotovoltaik modüllü hava sızdırmalı güneş toplayıcısının performans analizini yapmıştır [22]. Wang ve arkadaşları tarafindan hava sızdırmalı güneş toplayıcılarının nümerik simülasyonu yapılmıştır [23]. Budig ve Vajen, hava sızdırmalı güneş toplayıcılarının teorik ve deneysel incelemesini geliştirmişlerdir [24]. Leon ve Kumar güneş enerjisi ile kurutma için güneş duvarının analizini yapmıştır [25]. Leon, Augustus ve Kumar, hava sızdırmalı güneş toplayıcısının ısıl performans analizini ve matematiksel modellemesini yapmışlardır [26]. Lixin ve Hua, Çinin kuzeyinde inşa edilen hava sızdırmalı güneş toplayıcıs1 uygulamasının isıl analizini incelemişlerdir [27]. Motahar ve Alemrajabi, güneş duvarının ekserji analizini incelemiştir [28]. $\mathrm{Li}$ ve arkadaşları, güneş duvarına entegre edilmiş fotovoltaik sistemin performans analizini ve enerji modellemesini yapmışlardır [29, 30]. Vasan, rüzgarın güneş duvarı üzerindeki etkisini incelemişlerdir [31]. Chan ve Riffat, hava sıdırmalı güneş toplayıcılarının 1S1 transferi analizini incelemiştir [32]. Brown ve arkadaşları, güneş duvarı performansını etkileyen yönlendirme, eğim, ebat renk, kaplama türü ve bina türü gibi faktörleri dikkate alarak, İngiltere ve Galler'deki güneş duvarı kurulumları üzerine genel bir inceleme yapmıştır [33]. Zheng ve arkadaşları, soğuk iklim koşullarında hava sızdırmalı toplayıcı performansını arttırmak için yeni bir tasarım yapmışlardır [34]. Gao ve arkadaşları, soğuk iklim koşullarında kaplamalı hava sızdırmalı güneş toplayıcılarının hacim 1sıtma performansını test etmiştir [35]. Augustus ve Kumar, güneş duvarının 1sıl performansı için matematiksel modelleme yapmıştır [36]. Kozubal, ABD'deki farklı iklim koşullarındaki dokuz kent için güneş duvarı performansını simüle etmiştir [37]. Hall ve arkadaşları, hava sızdırmalı absorber panel üzerindeki seçici kaplamanın sistem üzerindeki etkisini incelemiştir [38]. Eryener, güneş 1şınımının düşük olduğu koşullarda bir tamamlayıcı 1sıtma sistemi olarak, k1lcal boru 1s1 değiştiricisi ile desteklenmiş güneş duvarı geliştirmiştir [39]. 
$\mathrm{Bu}$ çalışmada, Çayırova Kocaeli'nde faaliyet gösteren bir otomotiv tesisinde kurulmuş olan Türkiye'nin ilk hava sızdırmalı güneş duvarının performansı teorik ve deneysel olarak incelenmiştir. İnceleme, Şubat - Nisan 2013 ve Ocak-Mart 2014 dönemlerini kapsamaktadır. İki yıllık bir zaman diliminde kış dönemlerinde güneş duvarından sağlanan ve bina iç ortamına gönderilen enerji, bina yönetim sistemi izlenmiş ve elde edilen sonuçlar, güneş duvarı tasarımında kullanılan temel yazılım olan Retscreen verileri ile karşılaştırılmıştır. $\mathrm{Bu}$ inceleme, hava sızdırmalı güneş duvarlarının Türkiye'de iklim koşulları için performans tespitini yapan ilk çalışma olması itibariyle hava sızdırmalı güneş duvarlarının Türkiye'deki uygulanabilirliği hususunda temel bilgileri de içermektedir.

\section{HAVA SIZDIRMALI GÜNEŞ DUVARI}

Hava sızdırmalı güneş duvarı, Şekil 1'de gösterildiği üzere, metal malzemeden üretilmiş, uygulama tipine göre camlı veya camsız olarak binaların dış cephelerine monte edilen bir cephe kaplama sistemidir Sistemin en önemli elemanı güneş enerjisini absorbe eden hava sızdırmalı absorber paneldir. Absorber yüzey, üzerindeki çok sayıda özel tasarımlı milimetrik delikleri sayesinde, dış havayı güneş enerjisi ile ısıtarak iç ortama göndermektedir. Deliklerin çap1 1sıtılacak hava miktarına bağlı olarak projeye özel tasarlanmaktadır. $1 \mathrm{~m}^{2}$ absorber yüzeyde ortalama 2.500 adet hava sızdırma deliği bulunmaktadır. Sistemin diğer bir yapısal özelliği, absorber plakanın ön yüzeyinin güneş enerjisini emici özel bir kaplamaya sahip olmasıdır. Genel olarak koyu renklerden oluşan kaplama 0,95 'e varan emicilik değerleri sağlamaktadır. Bina cephesine uygulaması yapılan güneş duvarında üretilen 1s1 enerjisi, havalandırma kanalları vasitasıyla bina içine sevk edilir. Uygulama türüne bağlı olarak bazen tamamlayıcı bir 1sıtma sistemi, güneş duvarına entegre edilerek kullanılır, bu şekilde güneş enerjisinin yetersiz olduğu durumlarda güneş duvarı ön 1sitma vazifesi görür ve enerji tasarrufu sağlar. Hava sızdırmalı güneş duvarları yüksek verimli sistemlerdir. $\% 80$ ve hatta üzerine çıkabilen verim eğrileri mevcuttur. Şekil 2'de hava sızdırmalı güneş duvarının performans diyagramı yer almaktadır [40]. Verimin yüksek olmasının temel nedeni, absorber üzerinde hava akışının binlerce noktadan sızdırılarak sağlanması ve bu esnada sınır tabaka akış koşullarının oluşmasıdır, dolayısıyla klasik ısı geçişi sağlayan sistemlerde olduğu gibi, tek noktadan akışkan giriş ve çıkışı yerine, milyonlarca delikten giriş ve tek noktadan çıkış vardır. Dolayısıyla absorber yüzeyden dış ortama konveksiyonla 1s1 kayb1 ihmal edilecek seviyede gerçekleşmektedir, bu da sistemin verimliliğini, diğer sistemlere nazaran daha yüksek yapmaktadır.

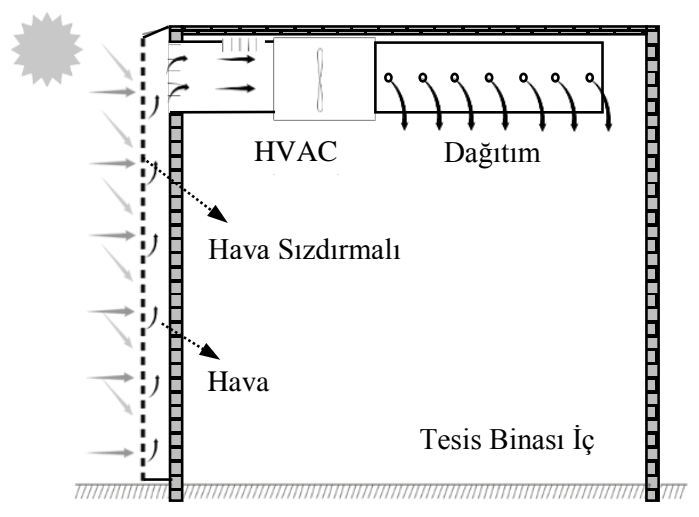

Şekil 1. Hava sızdırmalı güneş duvarı şematik resmi

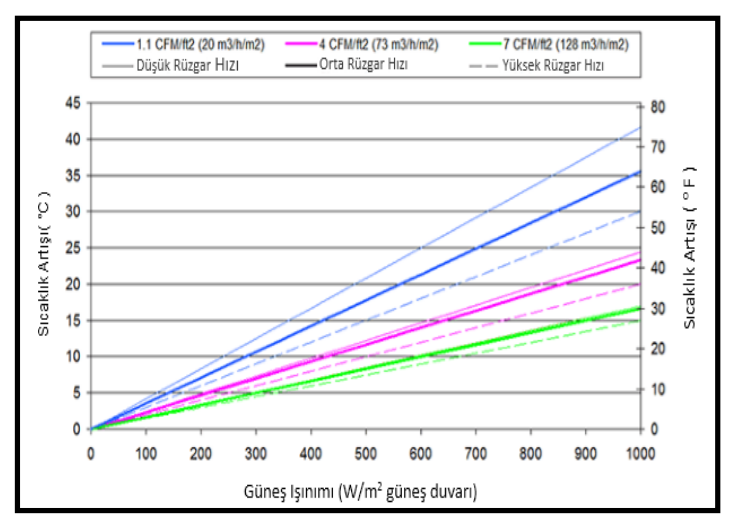

Şekil 2. Farklı rüzgar şiddetleri için hava sızdırmalı güneş duvarının sıcaklık performans diyagramı [40] 


\section{GÜNEŞ DUVARI ENERJİ DENGE DENKLEMLERI}

Güneş duvarı için genel enerji denge denklemleri Şekil 3'te verilen ve 1sı transferi mekanizmasını gösteren şematiğe dayanarak yazılabilir. Şekil 3 'te görüldüğü üzere, güneş duvarı, üç ayrı bileşene ayrılmaktadır ve her bir bileşen için literatürde önerilen 1S1 transferi denklemleri aşağıda verilmektedir [5, 6, 26].

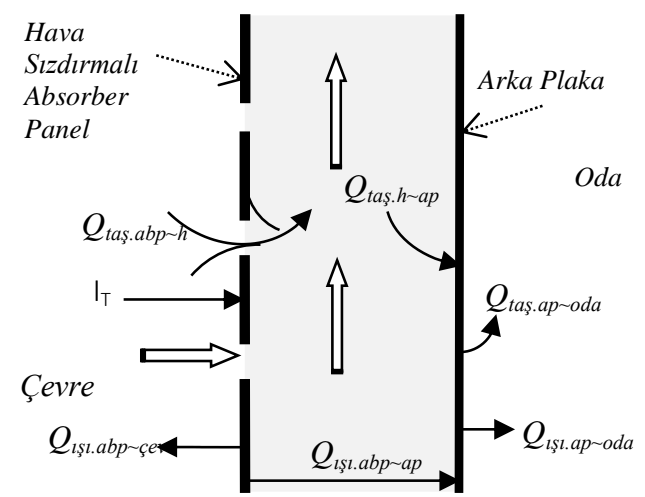

Şekil 3. Güneş duvarındaki 1S1 transferi mekanizmas

\subsection{Absorber Panel}

Absorber panel için sisteme enerji girişi, güneş 1şınımı ile gerçekleşen 1sı transferi ile olmaktadır. Sistemdeki net kayıplar, arka plakadan ve absorber panelden 1 şınım ve taşınım ile 1S1 transferi sebebiyle gerçekleşmektedir.

$\mathrm{m}_{\mathrm{abp}} \times \mathrm{c}_{\mathrm{p}, \mathrm{abp}} \times\left(\mathrm{dT}_{\mathrm{abp}} / \mathrm{dt}\right)=\left(\propto_{\mathrm{abp}} \times \mathrm{I}_{\mathrm{T}} \times \mathrm{A}_{\mathrm{abp}}\right)-$

$\left(\mathrm{Q}_{\text {taş.abp } \sim \mathrm{h}}+\mathrm{Q}_{1 \text { şı.abp } \sim \mathrm{ap}}+\mathrm{Q}_{\text {1şı.abp } \sim \text { çev }}\right)$

$Q_{\text {taş.abp } \sim h}$ terimi, absorber panelden havaya (absorber ön yüzeyinden, delik ve arka plakadan toplayıc1 iç ortam havasına yapılan 1sı transferini içeren) 1Sı kazancını ifade etmektedir. $Q_{\text {lşı.abp ap }}$, absorber panelden arka plakaya olan 1şınım ile 1sı transferini ifade etmektedir. $Q_{\text {lşı.abp } \sim c ̧ e v}$, absorber yüzeyden çevreye olan ışınım ile ısı kaybıdır. $m_{a b p}$ absorber panelin kütlesi, $c_{p, a b p}$ absorber panelin özgül 1sınma 1sısı, $T_{a b p}$ absorber panel sıcaklığıdır.

\subsection{Güneş Duvarı Boşluk Havası}

$\left(\dot{\mathrm{m}}_{\mathrm{h}} \times \mathrm{dt}\right) \times \mathrm{c}_{\mathrm{p}, \mathrm{h}} \times(\mathrm{dT} \mathrm{h} / \mathrm{dt})=\left(\mathrm{Q}_{\text {taş.abp } \sim \mathrm{h}}-\mathrm{Q}_{\text {taş.h } \sim \mathrm{ap}}\right)$

Denklem 8'deki $Q_{\text {taș.h ap }}$, toplayııı içindeki hava akımı ile arka plaka arasındaki 1s1 transferi ifadesidir. $m_{h}$ toplayıcı iç ortam havasının debisi, $c_{p, h}$ havanın özgül 1sınma 1 sısı, $T_{h}$ toplayıcı iç ortam havası sıcaklığıdır.

\subsection{Arka Plaka}

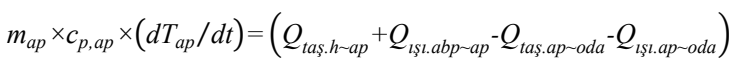

$Q_{\text {taș.ap oda }}$, arka plakadan mahal iç ortamına taşınım ile gerçekleşen isı transferini ifade etmektedir. $Q_{\text {lşı.ap oda }}$, arka plakadan mahal iç ortamına ışınım ile transfer edilen ısıdır. $m_{a p}$ arka plakanın kütlesi, $\mathrm{c}_{\mathrm{p} \text {,ap }}$ arka plakanın özgül ısınma 1sısı, $T_{a p}$ arka plaka sıcaklığıdır.

Enerji denklemlerine ilişkin genel 1S1 transferi korelasyonları ilgili literatürde mevcuttur ve $[5,6$, 9, 26, 41, 42, 43, 44] nolu kaynaklarda ayrıntılı şekilde verilmektedir.

\section{TÜRKIYY'DEKI HAVA SIZDIRMALI GÜNEŞ DUVARI UYGULAMALARI}

Hava sızdırmalı güneş duvarı sistemleri son dönemde Türkiye enerji pazarında satışa sunulmuştur. O tarihten bu yana çeşitli endüstriyel, ticari binalar ve konutlar için çok sayıda uygulaması yapılmıştır. Türkiye'de ilk güneş duvarı uygulaması, Kocaeli-Çayırova bir otomotiv üretim tesisinde 2012 yılında yapılmıştır. İlk uygulamadan bu yana geçen zaman zarfinda endüstriyel uygulamaların yaygınlık kazandığ gözlemlenmektedir. Çizelge 1'de Türkiye'de hava sıdırılmalı güneş duvarı kurulumunun yapıldığı başlıca endüstriyel binalar ve sistem özellikleri gösterilmektedir. 
Çizelge 1. Türkiye'de endüstriyel tesislere uygulaması yapılan hava sızdırmalı güneş duvarı sistemleri

\begin{tabular}{|c|c|c|c|c|c|c|}
\hline$\#$ & Konum & $\begin{array}{c}\text { Alan } \\
{\left[\mathrm{m}^{2}\right]}\end{array}$ & $\begin{array}{c}\text { Yön } \\
{[-]}\end{array}$ & $\begin{array}{c}\text { Renk } \\
{[-]}\end{array}$ & $\begin{array}{c}\text { Hava Debisi } \\
{\left[\mathrm{m}^{3} / \mathrm{h}\right]}\end{array}$ & Bina tipi \\
\hline 1 & Çayırova & 770 & G & Antrasit & 63720 & Otomotiv endüstrisi \\
\hline 2 & Çayırova & 800 & GB & Antrasit & 84000 & Otomotiv endüstrisi \\
\hline 3 & Gebze & 200 & G & Siyah & 30000 & Kontrol sistemi üretimi \\
\hline 4 & Dilovas1 & 1040 & GD ve GB & Gri & 108000 & Elektronik ürün üretimi \\
\hline 5 & Hendek & 100 & G & Siyah & 7500 & Otomotiv endüstrisi \\
\hline 6 & Bursa & 310 & G & Siyah & 35000 & Otomotiv endüstrisi \\
\hline 7 & Gebze & 100 & GD & Mavi & 15000 & Kimya endüstrisi \\
\hline 8 & İstanbul & 400 & G & Siyah & 37500 & Silah üretimi \\
\hline 9 & Dilovas1 & 400 & G & Siyah & 70000 & Kimya endüstrisisi \\
\hline 10 & Dilovas1 & 100 & G & Kahverengi & 7500 & Makine elemanları üretimi \\
\hline 11 & Çerkezköy & 2100 & GD ve GB & Siyah & 252000 & Havac1lik endüstrisi \\
\hline 12 & Ankara & 360 & G & Siyah & 40000 & \\
\hline
\end{tabular}

\section{TÜRKIYE'DEKİ ILK HAVA SIZDIRMALI GÜNES DUVARI UYGULAMASI}

\subsection{Bina Özellikleri}

Gebze TOSB sanayi bölgesinde yer alan tesis, iki katlı imalat atölyesi, ofis binası, bir depo, bir yardımcı servis binası, binanın batı ve güney sınırlarını çevreleyen açı otoparktan oluşmaktadır. Proje, iki katlı, toplam $12.275 \mathrm{~m}^{2}$ alana sahip fabrikanın isitma-havalandırma sistemine destek olacak şekilde tasarlanmıştır. Güneş duvarı sistemi, havalandırma havası 1sıtması, hava dengesinin sağlanması ve konfor koşullarının iyileştirilmesi, 1sı kayıplarının geri kazanımı, yardımc1 1sıtma sisteminin yakıt tüketimini azaltılması için tasarlanmıştır.

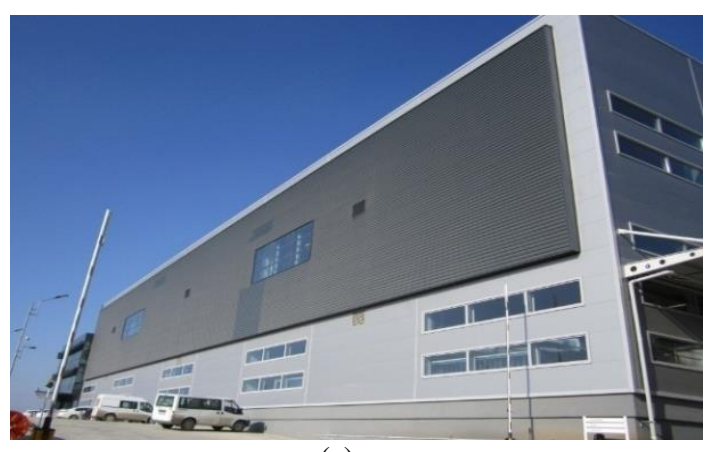

(a)

\subsection{Hava Sızdırmalı Güneş Duvarı Özellikleri}

Hava sızdırmalı güneş duvarı tesis binasının güney cephesinde $770 \mathrm{~m}^{2}$ alan büyüklüğünde monte edilmiştir. Bir katta üç adet olmak üzere güneş duvarı sisteminde altı adet tamamlayıc1 1sitma ve havalandırma santrali yer almaktadır. Her santral $2,95 \mathrm{~m}^{3} / \mathrm{s}$ debi ile taze hava sağlamakta ve fan kanalında güneş 1şınımı yetersiz olduğu zamanlarda kullanılmak üzere yardımcı 1sitma sistemi bulundurmaktadır (Çizelge 2). Şekil 4'te otomotiv üretim tesisi güneş duvarı ve güneş duvarına bağlı çalışan tamamlayıcı santral ünitesi görülmektedir. Şekil 5'te güneş duvarı planının ön görünüşü ve Şekil 6'da hava sızdırmalı güneş duvarı sisteminin ölçüm noktalarının şematik resmi yer almaktadır.

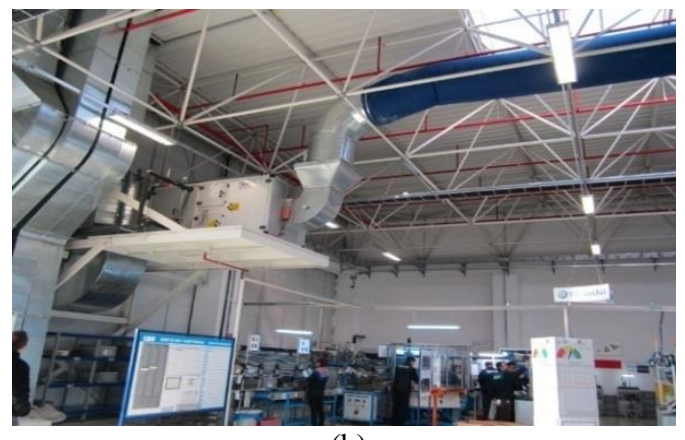

(b)

Şekil 4. Otomotiv üretim tesisi güneş duvarı sistemi (a) Güneş duvarı (b) Güneş duvarı hava kontrol ünitesi 


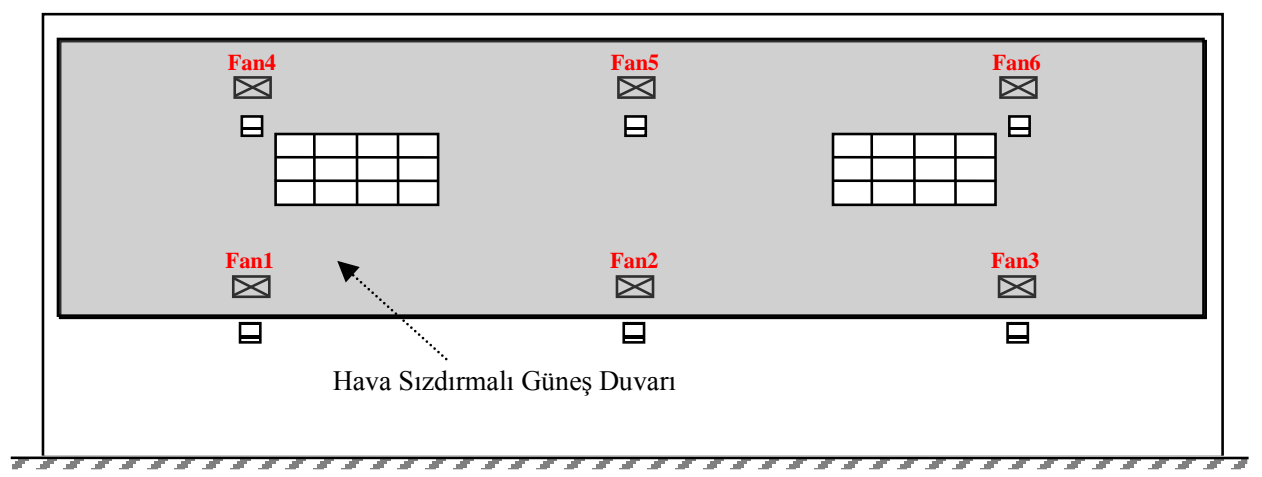

Şekil 5. Güneş duvarının ön görünüşü şeması

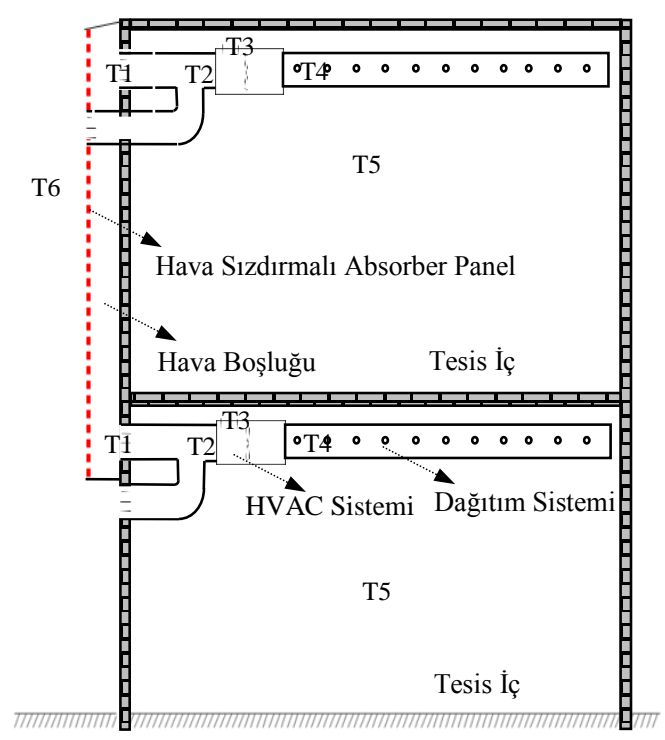

Şekil 6. Otomotiv üretim tesisi hava sızdırmalı güneş duvarı ölçüm noktalarının şematik resmi

Çizelge 2. Sistem sıcaklık ölçüm noktaları

\begin{tabular}{|c|l|}
\hline $\begin{array}{c}\text { Ölçüm } \\
\text { yeri }\end{array}$ & \\
\hline $\mathrm{T} 1$ & Güneş duvarı boşluk havası sıcaklığı \\
\hline $\mathrm{T} 2$ & Güneş duvarı çıkışı hava sıcaklığı \\
\hline $\mathrm{T} 3$ & $\begin{array}{l}\text { Bina iç ortam sirkülasyon havas1 } \\
\text { sicaklığ }\end{array}$ \\
\hline $\mathrm{T} 4$ & Hava dağıtım kanalı sıcaklığ1 \\
\hline $\mathrm{T} 5$ & Bina iç ortam sıcaklı̆̆ \\
\hline $\mathrm{T} 6$ & Diş ortam sıcaklığı \\
\hline
\end{tabular}

\section{3. Ölçüm ve İzleme}

Otomotiv üretim tesisi, bina yönetim sistemi olarak adlandırılan bilgisayar kontrollü bina otomasyon sistemi kullanılmaktadır. Bina yönetim sistemi, binalarda yaşanılan ve çalışılan iç ortamların gereksinimlerini karşılayan, 1sıtma, havalandırma, soğutma, enerji ve su dağıtımı, aydınlatma ve güvenlik sistemlerinin işletimini sağlayan, bilgisayar kontrollü otomasyon sistemidir. $\mathrm{Bu}$ sistem, bina işletimini kusursuz olarak gerçekleştirerek optimum işletim sağlamaktadır. Binadaki tesisat ve sistemlere yerleştirilen sensörler, vana ve damper motorları, 
açma kapama ekipmanları ve kontrol panelinden alınan bilgiler, yazılımın öngördüğü gibi değerlendirilmekte ve sistemin kontrolü yapılmaktadır. Sonuçlar internet aracılığı ile anında kullanıcıya iletilmektedir. Bina yönetim sistemi, operatörün ayarladığı parametrelere göre uzun veya kısa dönem verilerini hafizaya kaydederek sistem performansını değerlendirebilmektedir. Tesiste ofis binasının beş katına yerleştirilmiş otuz dokuz sıcaklık sensörü, güneş duvarı sisteminde kullanılan yirmi dört sıcaklık sensörü, imalat bölümündeki iç ortam sıcaklığını ölçen iki sensör, dış ortam hava sıcaklığını ölçen iki sensör ve güneş duvarının hava aktarım kanallarında yer alan yirmi dört damper bina yönetim sistemi kontrolündedir. Şekil 7'de, güneş duvarının performans ölçümünü için kullanılan altı fandan biri olan 5 nolu fana ait bina yönetim sistemi verileri görülmektedir.

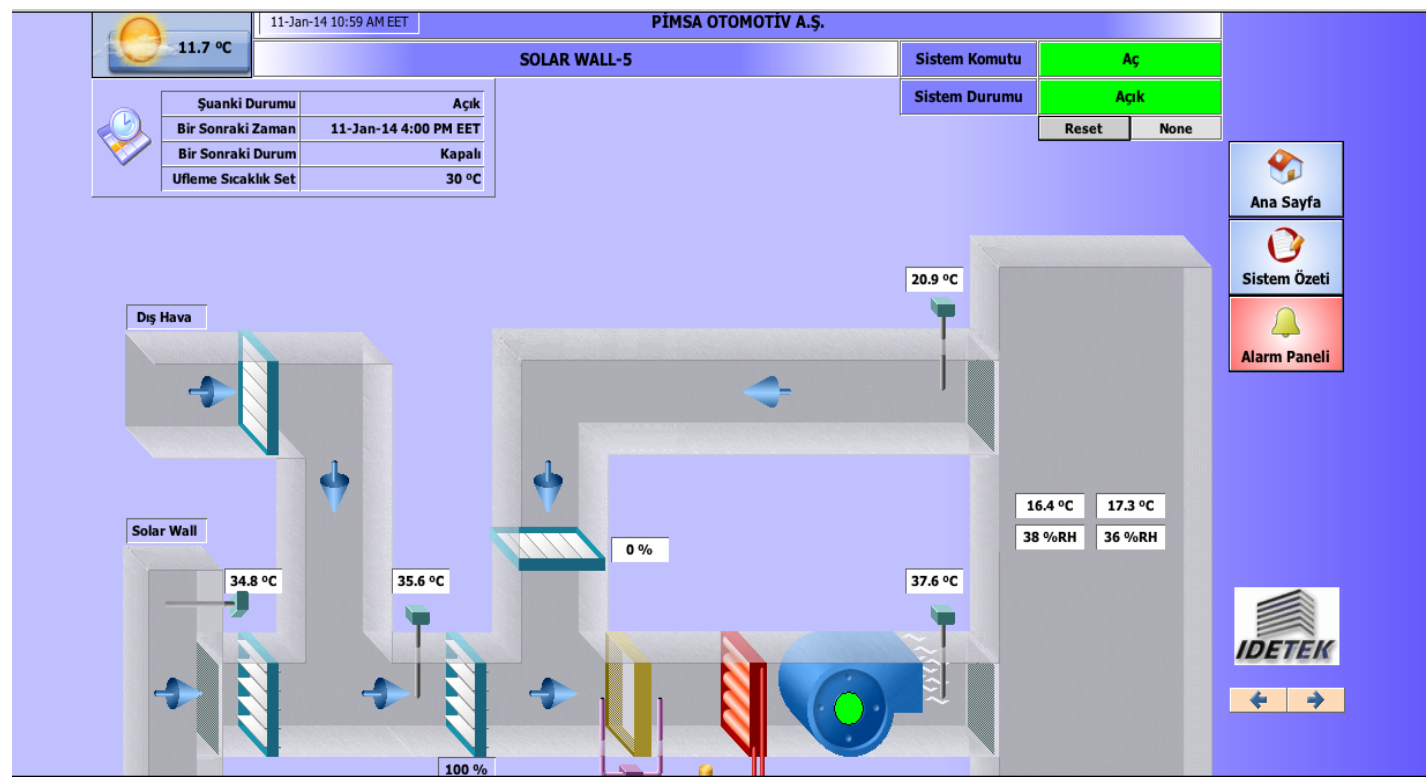

Şekil 7. 5 nolu fan sistemine ait güneş duvarı bina yönetim sistemi verileri

\section{RETSCREEN ANALIZİ}

Retscreen Temiz Enerji Proje Analiz Yazılımı, ilk olarak Kanada Hükümeti CANMET Enerji Araştırma Laboratuvarı tarafından sunulmuş, sanayiden ve akademik çevrelerden sayısız uzmanın katkısıyla geliştirilen bir enerji üretim sistemleri analiz programıdır. Ücretsiz elde edilebilen bu yazılım çeşitli konvansiyonel ve yenilenebilir enerji biçimlerinin üretim miktarlarını, çevreye etkilerini, teknik ve ekonomik uygulanabilirliklerini değerlendirmek üzere kullanılmaktadır [43]. Retscreen Microsoft Excel programı altyapısını kullanarak çalışmaktadır. Proje tipi olarak enerji verimliliği önlemleri, elektrik, 1sıtma, soğutma, kombine 1sitma ve güç, kombine soğutma ve güç, kombine 1sitma ve soğutma alanlarında analiz imkanı sunmaktadır. Teknoloji türü olarak, güneş enerjili hava 1sıtma, güneş enerjili su 1sıtma, 1sı pompas1, güneş 1s1 enerjisi, jeotermal enerji, rüzgar türbini, hidroelektrik santral, su türbini, yakıt hücresi, pistonlu motorlar, fotovoltaik sistemler üzerine proje analizi yapılabilmektedir. Program, güneş duvarı analizi ve boyutlandırmasında tercih edilen bir yazılımdir. Retscreen ile enerji modeli oluşturma, maliyet analizi, emisyon analizi ve ekonomik analiz yapabilmektedir. Retscreen iklim veri bankasında enlem, boylam, rakım değerleri, aylara göre hava sıcaklığı, bağıl nem, güneş radyasyonu, atmosferik basınç, rüzgar hızı, yer sıcaklığı, 1sıtma ve soğutma ihtiyaçları değerleri görülebilmektedir. 
Türkiye'de uygulaması yapılan ilk hava sızdırmalı güneş duvarının enerji tasarrufu, Retscreen analiz programı kullanılarak hesaplanmıştır. Retscreen simülasyon sonuçlarına göre iki yıllık zaman dilimindeki kış döneminde sistemden, 2013 yılında 95,165 kWh 1S1 enerjisi, 2014 y1lında $138,337 \mathrm{kWh}$ 1sı enerjisi üretilmiştir. Retscreen simülasyon sonuçları, 2013-2014 döneminde bina yönetim sisteminden alınan gerçek ölçüm verileri ile doğrulanmaktadır. Retscreen analizine göre, otomotiv üretim tesisi hava sızdırmalı güneş duvarı sera gazı emisyonlarını yılda 193,64 ton $\mathrm{CO}_{2}$ azaltmaktadır (Çizelge 3-5).

Çizelge 3. Tasarım parametreleri

\begin{tabular}{|l|c|}
\hline Parametre & Değer \\
\hline İç mekan set sıcaklığı & $20^{\circ} \mathrm{C}$ \\
\hline Hava sıcaklığ1-maksimum & $45^{\circ} \mathrm{C}$ \\
\hline Güneş duvarı alanı & $770 \mathrm{~m}^{2}$ \\
\hline $\begin{array}{l}\text { Güneş duvarı boşluk } \\
\text { derinliği }\end{array}$ & $0,35 \mathrm{~m}$ \\
\hline Hava debisi & $63.720 \mathrm{~m}^{3} / \mathrm{h}$ \\
\hline Güneş duvarı absorbsiyonu & 0,92 \\
\hline Azimut & 0,0 \\
\hline Ĕğim & $90^{\circ}$ duvar \\
\hline Bina taban alanı & $9.720 \mathrm{~m}^{2}$ \\
\hline R-değeri-çatı & $2,0 \mathrm{~m}^{2} .{ }^{\circ} \mathrm{C} / \mathrm{W}$ \\
\hline R-değeri-duvar & $1,5 \mathrm{~m}^{2} .{ }^{\circ} \mathrm{C} / \mathrm{W}$ \\
\hline İklim verisi yeri & $\mathrm{Çayırova}^{7124}$ \\
\hline Çalışma saati/günü & $7 / 24$ \\
\hline
\end{tabular}

Çizelge 4. Ortalama aylık güneş 1şınımı

\begin{tabular}{|c|c|c|}
\hline Ay & $\begin{array}{c}\text { Ortalama aylık } \\
\text { güneş 1şııııı- } \\
\text { yatay } \\
\mathrm{kWh} / \mathrm{m}^{2} / \text { ay }\end{array}$ & $\begin{array}{c}\text { Ortalama aylık } \\
\text { güneş 1şı1nım1- } 90^{\circ} \\
\mathrm{kWh} / \mathrm{m}^{2} / \text { ay }\end{array}$ \\
\hline Ocak & 2,402 & 4,658 \\
\hline Şubat & 2,482 & 3,088 \\
\hline Mart & 2,757 & 2,237 \\
\hline Nisan & 2,845 & 1,722 \\
\hline Mayıs & 2,781 & 1,671 \\
\hline Haziran & 2,637 & 1,638 \\
\hline Temmuz & 3,018 & 1,677 \\
\hline Ağustos & 3,274 & 1,834 \\
\hline Eylül & 3,311 & 2,408 \\
\hline Ekim & 2,898 & 3,191 \\
\hline Kasım & 2,702 & 4,894 \\
\hline Aralık & 2,437 & 5,531 \\
\hline Yıllık & 2,402 & 4,658 \\
\hline
\end{tabular}

Çizelge 5. Retscreen simülasyon özeti

\begin{tabular}{|l|l|c|c|}
\hline \multicolumn{2}{|c|}{} & $\begin{array}{c}\text { Ortalama } \\
\text { Değer }\end{array}$ & Birim \\
\hline \multirow{3}{*}{$\begin{array}{l}\text { Güneş enerjisi ile } \\
\text { 1sıtma }\end{array}$} & Ocak & 70,617 & $\mathrm{kWh}$ \\
\cline { 2 - 4 } & Şubat & 43,127 & $\mathrm{kWh}$ \\
\cline { 2 - 4 } & Mart & 33,242 & $\mathrm{kWh}$ \\
\cline { 2 - 4 } & Nisan & 27,446 & $\mathrm{kWh}$ \\
\hline $\begin{array}{l}\text { Y1llık net sera gazı } \\
\text { emisyonu azalmas1 }\end{array}$ & & 193,64 & $\mathrm{tCO}_{2}$ \\
\hline
\end{tabular}

\section{HAVA SIZDIRMALI GÜNEŞ DUVARI PERFORMANSI}

Çayırova'daki otomotiv üretim tesisine kurulumu yapılan hava sızdırmalı güneş duvarında, iki yıllık bir süre zarfında mahal 1sıtması yapılan kış dönemlerde üçer aylık periyodlarla ölçüm yapılmıştır. Sonuçlar, güneş duvarının çalıştığı Şubat-Nisan 2013 ve Ocak-Mart 2014 dönemlerine ait ölçüm verileri kullanılarak elde edilmiştir. Bina yönetim sisteminin ölçtüğü veriler ile güneş duvarından sağlanan enerji ve bina iç ortamına gönderilen enerji hesaplanmıştır.

Çizelge 6'da kWh cinsinden güneş duvarının sağladığı 1S1 enerjisi değerleri görülmektedir. Sonuçlar, Retscreen simülasyon sonuçları ile uyumludur. Otomotiv üretim tesisine kurulumu yapılan güneş duvarı izleme yapılan kış döneminde, 2013 yllında $113.037 \mathrm{kWh}$ enerji, 2014 yılındaki 246.924 kWh 1sı enerjisi üretmiştir. 2013 ve 2014 yıllarında üretilen enerji arasındaki fark güneş duvarının toplam çalışma saatlerinin farkından kaynaklanmaktadır.

Çizelge 6. Hava sızdırmalı güneş duvarının sağladığı enerji

\begin{tabular}{|l|c|c|}
\hline Ay & $\begin{array}{c}\text { Güneş duvarı } \\
\text { enerji üretimi, } \\
\mathbf{2 0 1 3 ,} \mathbf{~ k W h}\end{array}$ & $\begin{array}{c}\text { Güneş duvarı } \\
\text { enerji üretimi, } \\
\mathbf{2 0 1 4 ,} \mathbf{~ k W h}\end{array}$ \\
\hline Ocak & - & 105,741 \\
\hline Şubat & 30,918 & 83,117 \\
\hline Mart & 36,861 & 58,066 \\
\hline Nisan & 45,258 & - \\
\hline
\end{tabular}

Çizelge 7'de tesise kurulumu yapılan güneş duvarından elde edilen aylık ortalama enerji tasarrufunun, bağıl tasarrufun, aylık ortalama 1sıtma ihtiyacının ve aylık çalışma saatlerinin aylara göre değişimi yer almaktadır. Sistemden 
\%62 tasarruf elde edilmiștir. Ayrıca sistem, gece saatlerinde ve güneş ışınımının olmadığı saatlerde de duvardan 1Sı geri kazanımı ile ön 1sıtma yaparak tasarruf yapmaktadır.

Çizelge 7. Tesisteki aylık ortalama enerji tasarrufu ve 1sıtma ihtiyacı

\begin{tabular}{|l|c|c|c|c|}
\hline Tarih & $\begin{array}{c}\text { Aylık çalışma } \\
\text { saati (saat) }\end{array}$ & $\begin{array}{c}\text { Aylık Ortalama Isıtma } \\
\text { İhtiyacı (kWh) }\end{array}$ & $\begin{array}{c}\text { Aylık Ortalama Enerji } \\
\text { Tasarrufu (kWh) }\end{array}$ & $\begin{array}{c}\text { Bağıl Tasarruf } \\
(\%)\end{array}$ \\
\hline Aralık 2012 & 5,58 & $73.331,39$ & $40.064,27$ & $54,63 \%$ \\
\hline Şubat 2013 & 5,25 & $54.745,89$ & $30.918,52$ & $56,48 \%$ \\
\hline Mart 2013 & 7.21 & $68.835,79$ & $36.861,74$ & $53,55 \%$ \\
\hline Nisan 2013 & 8,07 & $73.264,58$ & $45.258,05$ & $61,77 \%$ \\
\hline Aralık 2013 & 16,37 & $253.484,73$ & $105.403,83$ & $41,58 \%$ \\
\hline Ocak 2014 & 19,49 & $229.873,61$ & $105.741,72$ & $46,00 \%$ \\
\hline Şubat 2014 & 18,59 & $211.781,12$ & $83.117,42$ & $39,25 \%$ \\
\hline Mart 2014 & 20,49 & $171.273,54$ & $58.066,02$ & $33,90 \%$ \\
\hline
\end{tabular}

Şekil 8-12, güneş duvarının performansını göstermektedir. Aşağıdaki şekillerde hava sızdırmalı güneş duvarının kış aylarında etkin 1sıtma sağladığ 1 ve performansının yüksek olduğu görülmektedir. Güneşli günlerde sıcaklık artışının $45^{\circ} \mathrm{C}^{\prime}$ ye ulaştı̆̆ 1 ve $\% 100$ 1sıtma tasarrufu sağladiğ1 ölçülmüştür. Şekil 8 'de, Retscreen simülasyon sonuçlarından elde edilen ve hava sızdırmalı güneş duvarından ölçülen ortalama sıcaklık farkı değerlerinin arasında farklılıklar görülmektedir. Retscreen ortalama 1 şınım değerlerine göre hesaplama yaptığ simülasyon değerleri, güneş duvarından ölçülen sıcaklık farkı değerlerinden daha düşüktür. Tesisteki hava sızdırmalı güneş duvarından ölçülen sıcaklık farkı ise sistemin çalışma saatlerindeki güneş 1şınımıyla, dolayısıyla hava açıklık oranıyla ilgilidir. $\mathrm{Bu}$ farklılık ölçüm yapılan saatlerdeki güneş 1 şınım şiddetinin, günlük ortalama 1 şınım şiddetinden daha yüksek olmasından kaynaklanmaktadır. Güneş duvarı havanın açık olduğu zamanlar çalıştırıldığı için elde edilen sıcaklık artışı daha yüksektir.
Sıcaklık artışı, güneş duvarı absorber plakasına gelen güneş 1 şınımı ve dış ortam hava sıcaklığı ile doğru orantılı olarak değişmektedir. Isıtmasının yapıldığı kış aylarında dik duvara gelen 1şınım, diğer aylara göre daha yüksek değerdedir. Dolayısıyla Aralık ayından Nisan ayına doğru ilerleyen günlerde dik duvara gelen günlük ortalama güneş 1şınımında ve hava sızdırmalı güneş duvarındaki sıcaklık farkında azalma görülmektedir.

Şekil 11'de görüldüğü gibi güneş duvarı, kış ayları boyunca çok verimli bir 1sıtma sağlamaktadır. Güneşli günlerde $16^{\circ} \mathrm{C}-45^{\circ} \mathrm{C}$ aralığında sıcaklık artışına ulaşılmaktadır. Şekil 10'da, diş hava sıcaklığı $3^{\circ} \mathrm{C}$ değerindeyken mahal iç ortamına $45^{\circ} \mathrm{C}$ 'de taze hava transferi yapilabilmektedir. Sistem, yılda $500-700 \mathrm{kWh} / \mathrm{m}^{2}$ lik $1 \mathrm{~S} 1$ üretimi sağlamaktadır

Hava sızdırmalı güneş duvarı verimi \%60 - 80’dir. Isıtma ve havalandırma işlemleri için enerji tüketimini ortalama $\% 40$ oranında azaltmaktadır. 
En önemli özelliklerinden biri, 1sıtma yaparken havalandırma işlemleri bir arada yapılmaktadır. taze hava kullanılmasidır. Böylece isitma ve

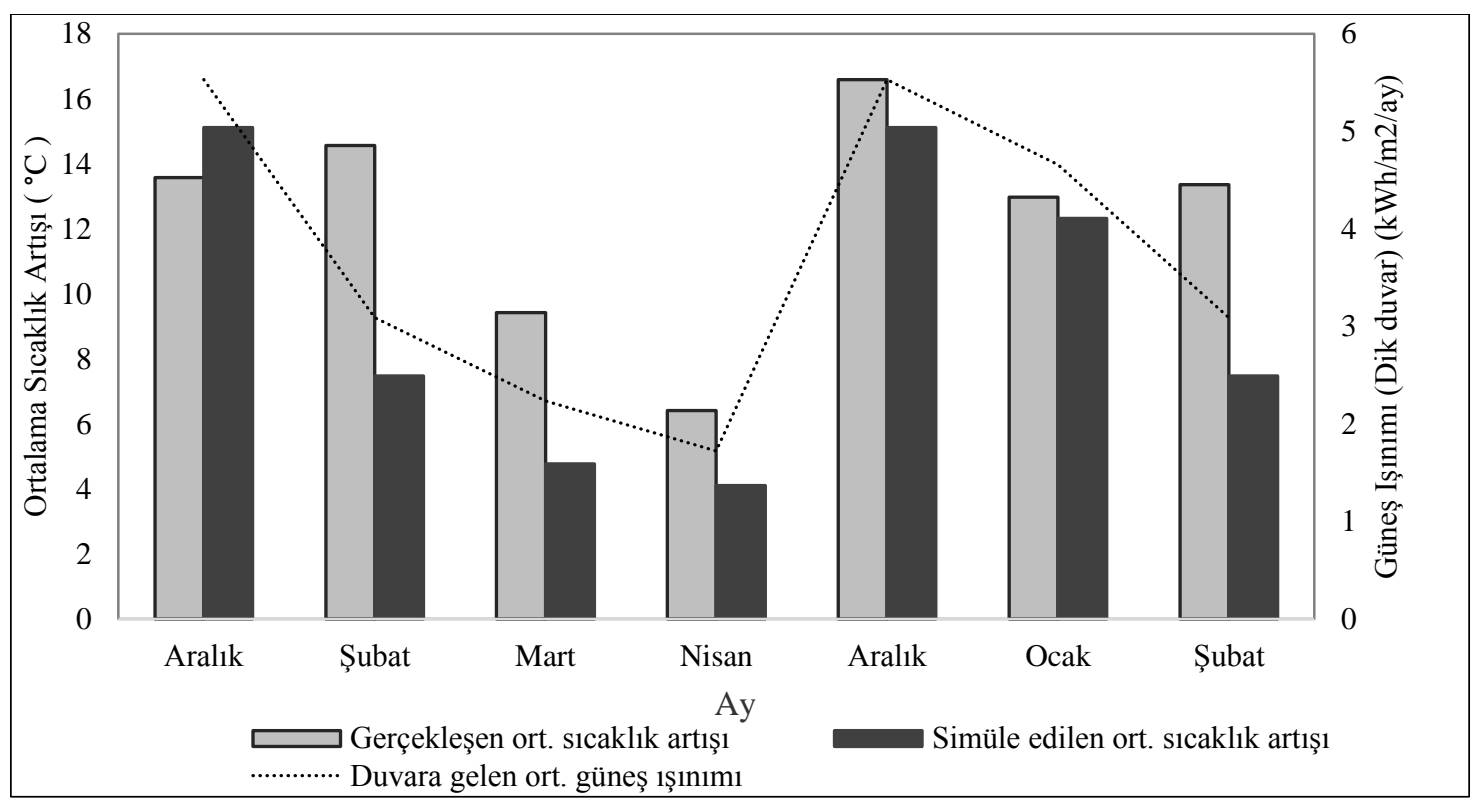

Şekil 8. Tesis verileri ve Retscreen analizi ile elde edilen güneş duvarı ortalama sıcaklık artışının dik yüzeye gelen güneş ışınımı ile değişimi

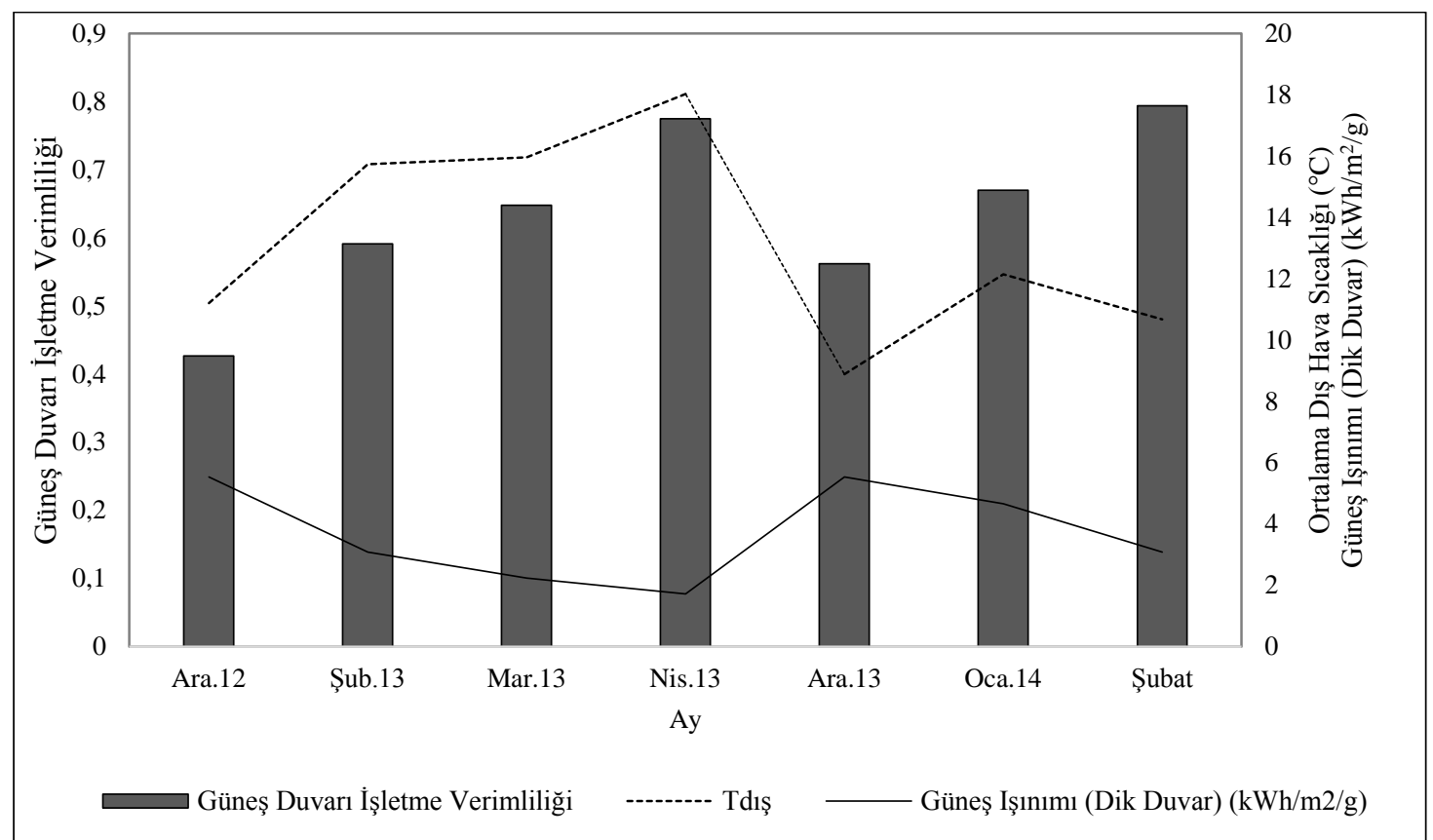

Şekil 9. Deney yapılan süreçte, güneş 1şınımı, dış hava sıcaklığı ve güneş duvarı işletme verimliliği değişimi 


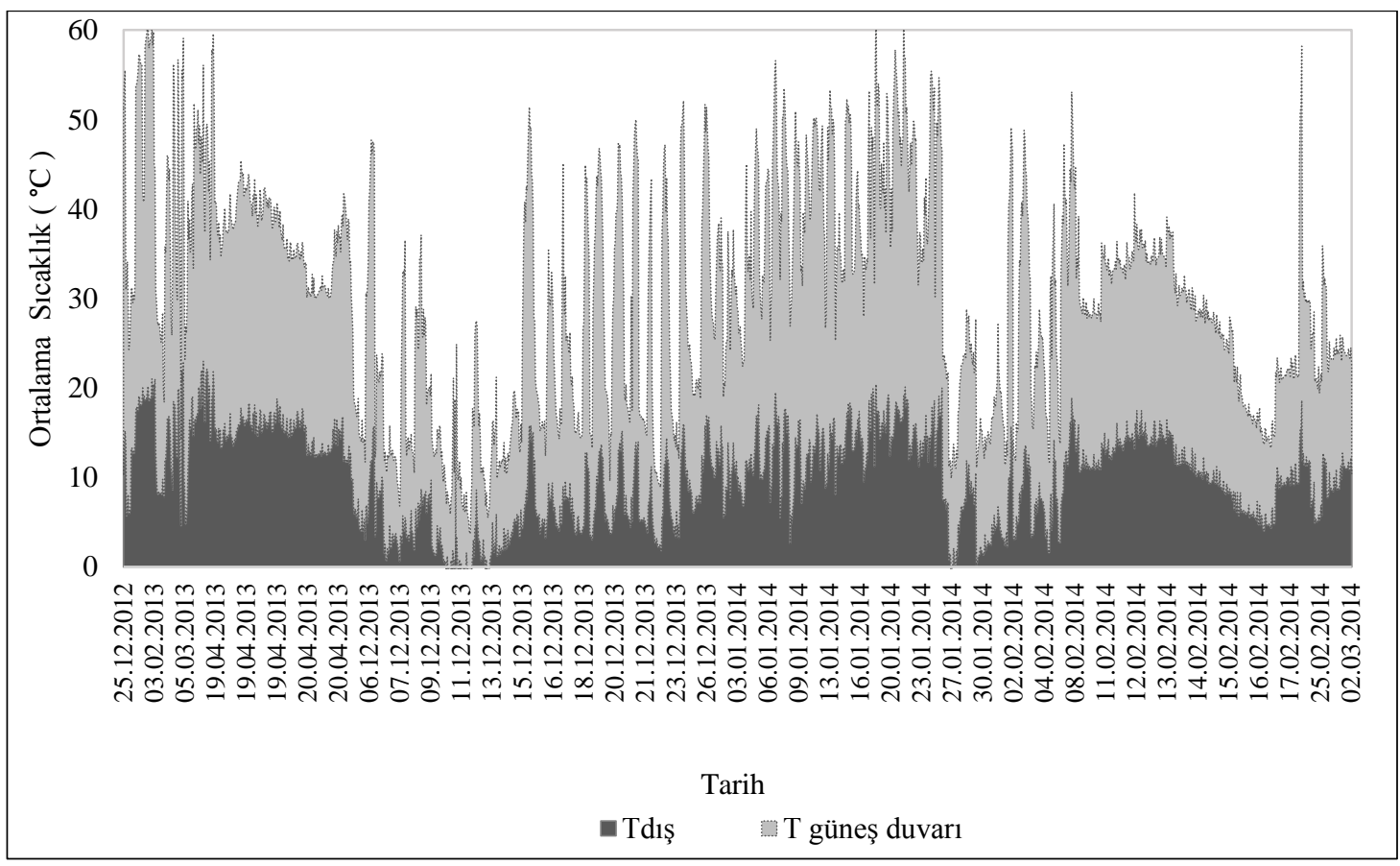

Şekil 10. Güneş duvarı ortalama çıkış sıcaklığının ve dış hava sıcaklığının zamanla değişimi

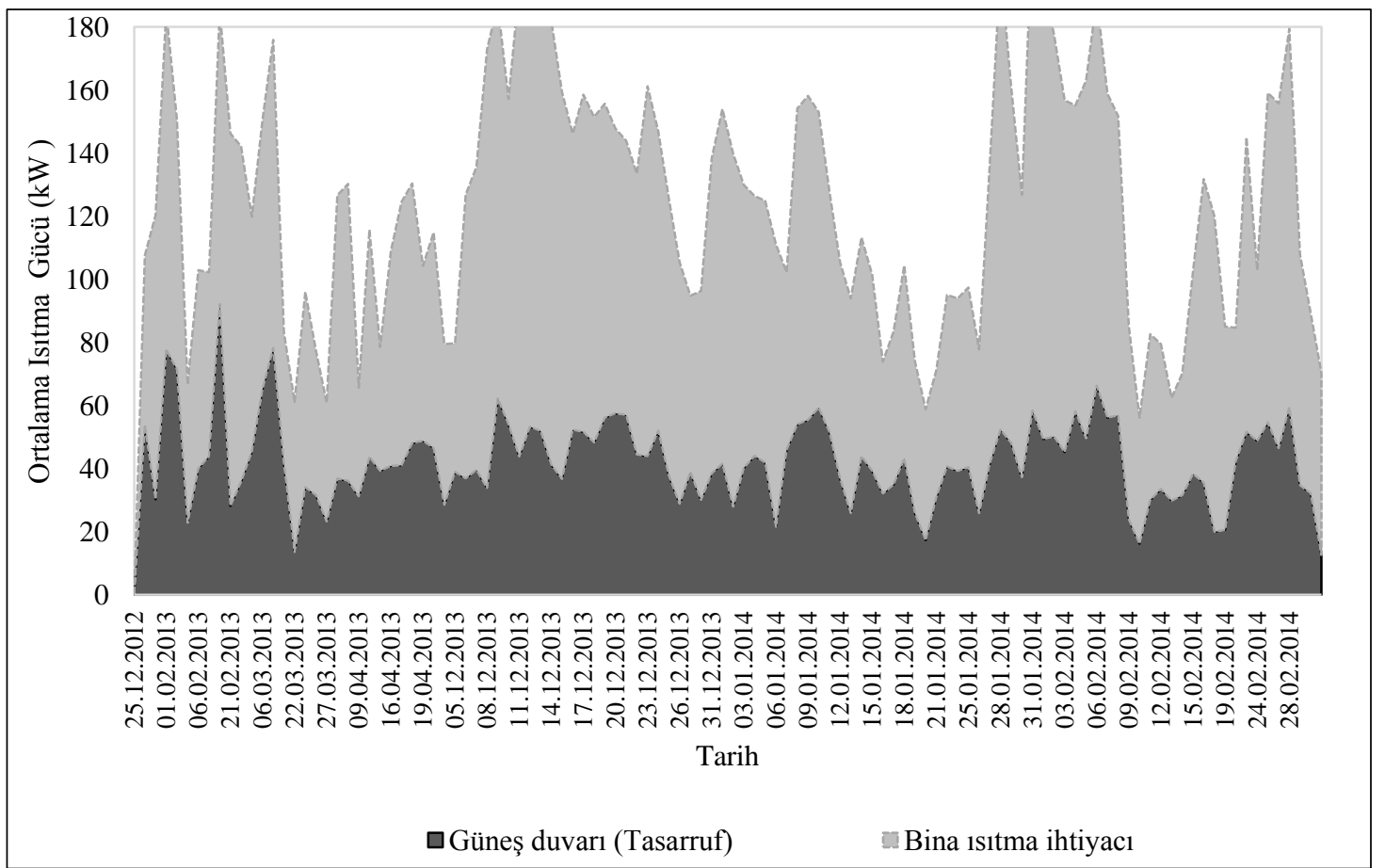

Şekil 11. Otomotiv üretim tesisi güneş duvarı ile tasarruf edilen ortalama 1sıtma gücünün ve bina 1sıtma ihtiyacının zamanla değişimi 


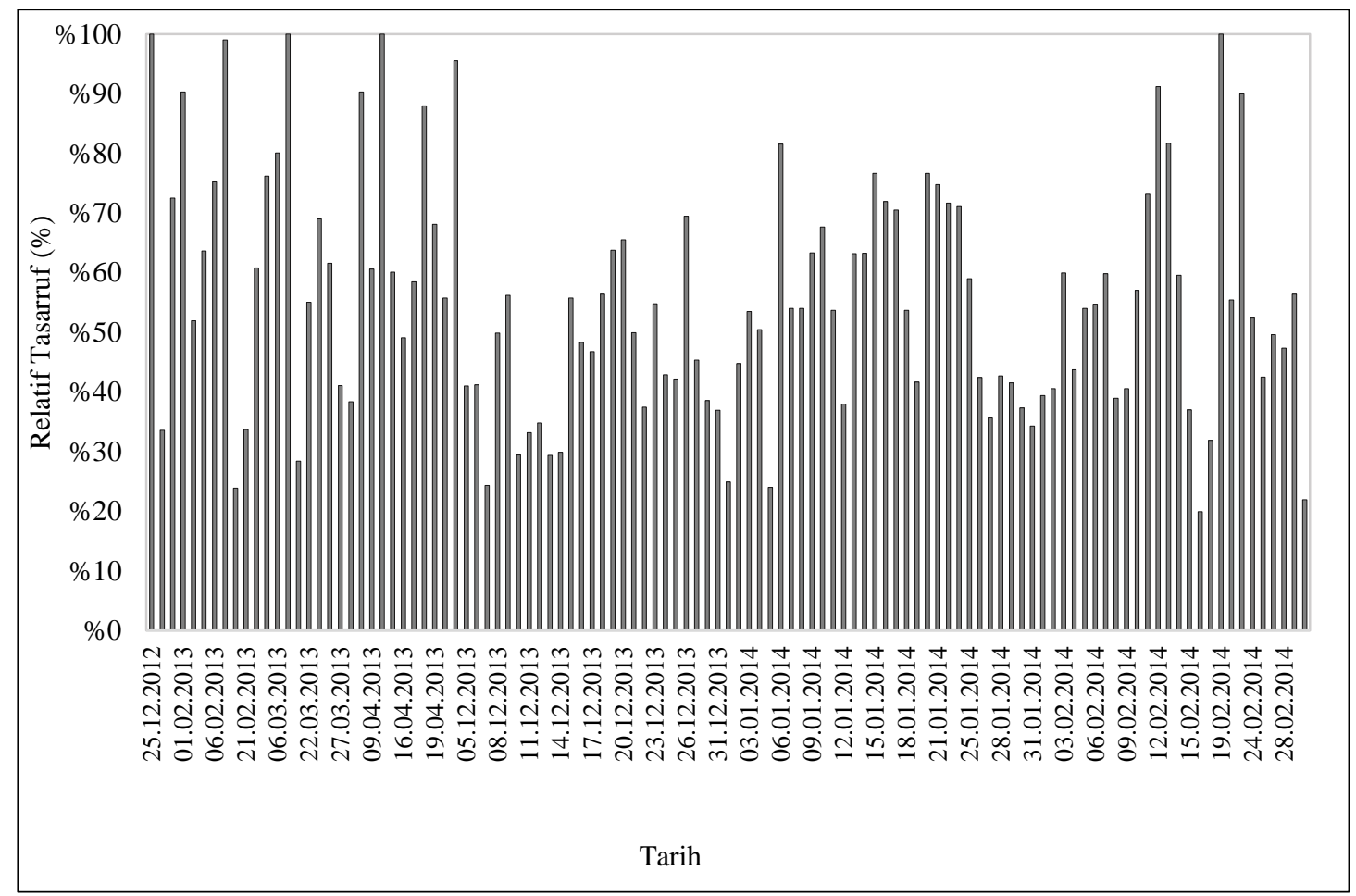

Şekil 12. Otomotiv üretim tesisi güneş duvarı ile sağlanan günlük relatif tasarrufun zamanla değişimi

\section{SONUÇLAR}

$\mathrm{Bu}$ çalışmada, hava sızdırmalı güneş duvarı sisteminin Türkiye iklim koşullarında endüstriyel binalardaki uygulamasının uygulanabilirliği incelenmiş ve deneysel olarak performans analizi yapılmıştır. Bu kapsamda, Çayırova'da otomotiv üretim tesisine kurulumu yapılan sistem verileri iki yıllık bir dönem boyunca incelenmiş ve sistemin 1sıtma kapasitesi, etkinliği belirlenmiştir. $\mathrm{Bu}$ çalışmadaki, güneş duvarı ile elde edilecek etkinlik değeri \% 75-80'e yakın değerlerdedir. Sistemde 1sıtma yaparken taze havanın kullanılmasıla, 1sıtma ve havalandırma işlemleri bir arada yapılarak enerji tüketimini azaltılmaktadır. Hava sızdırmalı güneş duvarı sıcak hava üretimi ve yüksek düzeyde yalıtım sağlamaktadır. Güneş enerjisi olmadığı zamanlarda da enerji korunumuna devam etmektedir. Sistem ayn1 zamanda yaz aylarında, gündüz pasif, gece ise aktif soğutma ile tasarruf sağlamaktadır. Sistem hem isitma hem de enerji tasarrufu yapmakta ve enerji maliyetini azaltmaktadır. Bütün özellikleriyle hava sızdırmalı güneş duvarı, çevresel sorunları önleyebilecek, enerji tüketimini azaltıp tasarruf sağlayacak olan güneş enerjisi ile hava 1sıtma sistemi olarak ön plana çıkmaktadır. Türkiye'deki güneş enerjisi potansiyeli diğer enerji türlerine kıyasla çok daha yüksek olmasına rağmen, güneş toplayıcıları ağırlıklı olarak müstakil evlerde su 1sitma amaciyla kullanılmaktadır. Hava sızdırmalı güneş duvarı, tüm dünyada sıcak hava üretimi için yaygın olarak kullanılmasına rağmen, Türkiye'de nispeten bilinmeyen ve az uygulaması olan bir teknolojidir. $\mathrm{Bu}$ çalışma, hava sızdırmalı güneş duvarının Türkiye'de başarılı bir şekilde uygulanabileceğini göstermektedir.

\section{KAYNAKLAR}

1. Mauthner, F., Weiss, W., Spörk-Dür, M., 2016. SHC International Energy Agency, Solar Heat Worldwide-Markets and Contribution to the 
Energy Supply 2014, IEA Solar Heating \& Cooling Programme.

2. Balcomb, J. D., 1992, Passive Solar Buildings, MIT Press.

3. Hordeski, M. F., 2002, New Technologies for Energy Efficiency, The Fairmont Press, Marcel Dekker, New York and Basel, ISBN 0-88173369-5.

4. Hollick, J.C., 2003. Unglazed Solar Wall Air Heaters, Conserval Engineering Inc., 200 Wildcat Rd. Downsview, Ontario M3J 2N5, Canada,

5. Kutscher, C.F., 1993. An Investigation of Heat Transfer for Air Flow Through Low Porosity Perforated Plates, University of Colorado, Boulder, s.289.

6. Kutscher, C.F., Christensen, C., Barker, G. 1993. Unglazed Transpired Solar Collectors: Heat Loss Theory. ASME Journal of Solar Engineering, Cilt. 115, s. 182-188.

7. Cao, S., Hollands, K.G.T., Brundrett, E., 1993. Heat Exchange effectiveness of unglazed transpired-plate solar collector in 2D flow.In: Proceedings of ISES Solar World Congress 1993, Budapest, Hungary, Vol. 5, pp. 351-366.

8. Pesaran, A.A., Wipke, K., 1994. Use of unglazed transpired solar collectors for desiccant cooling. Solar Energy Journal 52 (5); 419-427.

9. Kutscher, C.F., 1994. Heat Exchanger Effectiveness and Pressure Drop for Airflow Through Perforated Plates, With and Without Cross Wind. ASME Journal of Heat Transfer 116, 391-399.

10. Van Decker, G.W.E., Hollands, K.G.T., Brunger, A.P., 1996. Heat Exchange Effectiveness of Unglazed Transpired-plate Solar Collector in 3D Flow. In: Goietzburger, A., Luther, J. (Eds.), Proceedings of Euro Sun 96, Freiburg, Germany. DGS-Sonnenenergie Verlags GmbH, Munchen, Germany, pp.130-846.

11. Van Decker, G.W.E., Hollands, K.G.T., 1999. An Empirical Heat Transfer Equation for the Transpired Solar Collectors, Including no-wind Conditions. In: Proceedings of the ISES 99 Solar World Congress, Australia.

12. Van Decker, G.W.E., Hollands, K.G.T., Brunger, A.P., 2001. Heat Exchange Relations for Unglazed Transpired Solar Collectors With Circular Holes on a Square or Triangular Pitch. Solar Energy 71 (1), 33-45.

13. Campbell-Howe, R., 1996. Thermal Simulation and Economic Assessment of Unglazed Transpired Collestor Systems, The 1996 American Solar Energy Society Annual Conference, Asheville, North Carolina, April 13-18.

14. Dymond, C., Kutscher, C., 1997. Development of a Flow Distribution and Design Model for Transpired Solar Collectors. Solar Energy, 60 (5); 291-300.

15. Dymond, C., Kutscher, C.F., 1997. Development of a Flow Distribution and Design Model for Transpired Solar Collectors. Solar Energy, 60(5):291-300.

16. Christensen, C., 1998. Transpired Collectors (Solar Preheaters for Outdoor Ventilation Air), In: Program FEM.

17. Arulanandam, S.J., Hollands, K.G.T., Brundrett, E., 1999. A CFD Heat Transfer Analysis of the Transpired Solar Collector under No-wind Conditions. Solar Energy 67 (1-3), 93-100.

18. Gunnewiek, L.H, Brundrett, E., Hollands, KGT., 1996. Flow Distribution in Unglazed Transpired Plate Solar Air Heaters of Large Area. Solar Energy, 58; 227-37.

19. Gunnewiek, L.H., Hollands, K.G.T., Brundrett, E., 2002. Effect of Wind on Flow Distribution in Unglazed Transpired-plate Collectors. Solar Energy, Cilt:72, s.317-25.

20. Maurer, C.C., 2004. Field Study and Modeling of an Unglazed Transpired Solar Collector System, Yüksek Lisans Tezi, Mechanical and Aerospace Engineering, North Carolina State University.

21. Gawlik, K., Christensen, C., Kutscher, C., 2005. A Numerical and Experimental Investigation of Low-conductivity Unglazed, Transpired Solar Air Heaters. Journal of Solar Energy Engineering, Transactions of the ASME.; Cilt. 127: s.153-5.

22. Naveed, A.T., Kang, E.C., Lee, E.J., 2006. Effect of Unglazed Transpired Collector on the Performance of a Polycrystalline Silicon Photovoltaic Module, Journal of Solar Energy Engineering, 128, pp. 349-353. 
23. Guan, W., Wang, Z.H., 2006. Numerical Simulation Study on Transpired Solar Air Collector, Renewable Energy Resources and Greener Future, ICEBO2006, Shenzhen, China.

24. Frank, E., Budig, C., Vajen, K., 2006. Experimental and Theoretical Investigation of Unglazed Transpired Air Collectors in a Multicomponent Solar Thermal System, Proc. Eurosun 2006, Glasgow (UK), 27.-29.6.06.

25. Augustus Leon, M., Kumar, S., 2007. Mathematical Modeling and Thermal Performance Analysis of Unglazed Transpired Solar Collectors, Solar Energy, 81, 62-75.

26. Augustus Leon, M., Kumar, S., 2007. Mathematical Modeling and Thermal Performance Analysis of Unglazed Transpired Solar Collectors. Augustus. Solar Energy (0038-092X)1/1/. Cilt. 81, Iss.1; s.62-75.

27. Lixin, G., Hua., B., 2009. Study on the Application Potential of Solar wall System in Northern China. Power and Energy Engineering Conference, APPEEC 2009. AsiaPacific (978-1-4244-2486-3), s.4-4.

28. Motahar, S., Alemrajabi, A.A., 2010. An Analysis of Unglazed Transpired Solar Collectors Based on Exergetic Performance Criteria, International Journal of Thermodynamics. Cilt: 13, s. 153-60.

29. Li, S., Karava, P., 2014. Energy Modeling of Photovoltaic Thermal Systems With Corrugated Unglazed Transpired Solar Collectors-Part 2: Performance Analysis, Solar Energy, Cilt. 102, s. 297-307.

30. Li, S., Karava , P., Currie, S., Lin , W. E., Savory, E., 2014. Energy Modeling of Photovoltaic Thermal Systems With Corrugated Unglazed Transpired Solar Collectors-Part 1: Model development and validation, Solar Energy, Cilt. 102, s. 282-296.

31. Vasan, N., Stathopoulos, T., 2014, Experimentalstudy of Wind Effects on Unglazed Transpired Collectors, Solar Energy, Cilt. 101, s. 138-149.

32. Chan, H.Y., Zhu, J., Riffat, S., 2013. Heat Transfer Analysis of the Transpired Solar Facade, Energy Procedia, Cilt 42, s. 123-132.

33. Browna, C., Perisogloua, E., Halla, R., Stevenson, V., 2014. Transpired Solar
Collector Installations in Wales and England, Energy Procedia, Cilt. 48, s.18-27.

34.Zheng, W., Li, B., Zhang, H., You, S., Li, Y., Ye, T., 2016. Thermal Characteristics of a Glazed Transpired Solar Collector With Perforating Corrugated Plate in Cold Regions, Energy, Cilt. 109, s. 781-790.

35. Gao, L., Bai, H., Mao, S., 2014. Potential Application of Glazed Transpired Collectors to Space Heating in Cold Climates. Energy Conservation and Management, Cilt. 77, s. 690-699.

36. Augustus Leon, M., Kumar, S., 2007. Mathematical Modelling and Thermal Performance Analysis of Unglazed Transpired Solar Collectors. Solar Energy, Cilt:81, s.62-75.

37. Kozubal, E., Deru, M., Slayzak, S., Norton, P., Barker, G., McClendon, J., 2008. Evaluating the Performance and Economics of Transpired Solar Collectors for Commercial Applications. Proceedings of 2008ACEEE Summer Study on Energy Efficiency in Buildings, Pacific Groove, CA, USA.

38. Hall, R., Blower, J., 2016. Low-emissivity Transpired Solar Collectors, Energy Procedia, Cilt. 91, s. 56-63.

39. Eryener, D., 2009. Metal Cladding System with a Heat Exchanger System, Turkish Patent Institute.

40. www.solarwall.com

41. Kramer, K.S., 2013. IEA-SHC TASK 43: Solar Rating and Certification Procedures, Solar Heating \& Cooling Programme International Energy Agency.

42. Summers David, N., 1996. Thermal Simulation and Economic Assessment of Unglazed Transpired Collector System. Wisconsin Energy Bureau, University of Wisconsin, USA,

43. Cengel, Y.A., Turner, R.H., 2001, Fundamentals of thermal-fluid sciences, McGraw-Hill, Boston, 609.

44. Martin, M., Berdahl, P., 1984. Characteristics of infrared sky radiation in the United States, 